\section{Gähnen beim Feten}

Gähnen ist ein Reflex, bei dem Mund und Kiefer unwillkürlich weit geöffnet werden. Hinzu kommen eine lange und tiefe Luftinhalation durch Mund und Nase und eine langsame Expiration [1]. Dieser Reflex kann beim Menschen und bei vielen Wirbeltieren beobachtet werden, bereits intrauterin bis hin zum Erwachsenenalter. Man findet ihn auch in Verbindung mit anderen motorischen Aktivitäten, wie z.B. bei Streckbewegungen [2]. Beim Menschen dauert der Gähnvorgang etwas 6s, wobei sich die individuelle Gähndauer und -häufigkeit erstaunlich stabil verhalten [3].

Gähnen ist phylogenetisch gesehen ein altes und häufiges Phänomen, das im Laufe der Jahrhunderte zahlreiche Hypothesen über dessen Bedeutung entstehen ließ. In den beiden Haupttheorien zum Gähnen werden entweder die physiologische oder die soziale Bedeutung hervorgehoben.

Innerhalb der physiologischen Theorie wurden mehrere weitere Hypothesen entwickelt (Review siehe [4]). Unter diesen war die Respirations- und Kreislauftheorie die erste, die in der Literatur erwähnt wurde. Seit Hippokrates im 4. Jahrhundert vor Christi haben seine Schüler die Ansicht vertreten, dass Gähnen „schlechte Luft" aus der Lunge entfernen und den Sauerstofftransport zum Gehirn fördern könnte [5]. Nach dieser Hypothese wird Gähnen dann ausgelöst, wenn eine ungenügende Blut- oder Gehirnoxygenierung besteht oder wenn der Sauerstoffgehalt sinkt und die $\mathrm{CO}_{2}$-Konzentration steigt. Im Gegensatz dazu wird bei Patienten mit Herz- oder Lungenerkrankungen, bei denen häufig eine Hypoxie vorkommt, keine gesteigerte Gähntätigkeit gefunden. Ein gutes Beispiel gegen die respiratorische Theorie ist auch, dass anhaltende psychogenbedingte Hyperventilation mit nachfolgender Hypokapnie bei einigen Patienten mit automatischen Bewegungen inkl. Gähnen vergesellschaftet ist [6].

\section{Fetal Yawning}

Yawning is a reflex that consists of an involuntary wide opening of the mouth, with maximal widening of the angle of the jaw, long and deep air inhalation through the mouth and nose, and a slow expiration [1]. This reflex can be observed in humans and in many vertebrate species, from intrauterine to adult life. It can be accompanied by other facultative motor acts such as stretching [2]. In humans, a yawn last about six seconds and the individual yawn duration and frequency remains remarkably stable [3].

Phylogenetically speaking, yawning is an old and frequent phenomenon. It has always attracted the attention of researchers throughout the centuries, which developed a large number of hypotheses on regarding the function of yawning. The two main theories try to emphasize either a physiological or a social role of yawning.

Within the physiological role theory, several hypotheses were further developed (for review see [4]). Among them the respiratory and circulatory one hypothesis was the first to be mentioned in the literature. Since Hippocrates in the 4th century BC, scholars have thought that yawning might remove "bad air" from the lungs and increase the oxygen circulation of the brain [5]. According to this hypothesis, yawning is triggered when blood or brain oxygenation is insufficient or when the oxygen level drops and the $\mathrm{CO}_{2}$ concentration rises. Conversely, patients with heart or lung disease, in whom hypoxia is frequent, no increased yawning is observed. A good argument against the respiratory theory is also prolonged psychogenic hyperventilation with consecutive hypocapnia which has been reported to be associated with automatic movements including yawns in some patients [6].

The evidence against the respiratory hypothesis had resulted in the arousal hypothesis. Arousals are defined as a global activati-

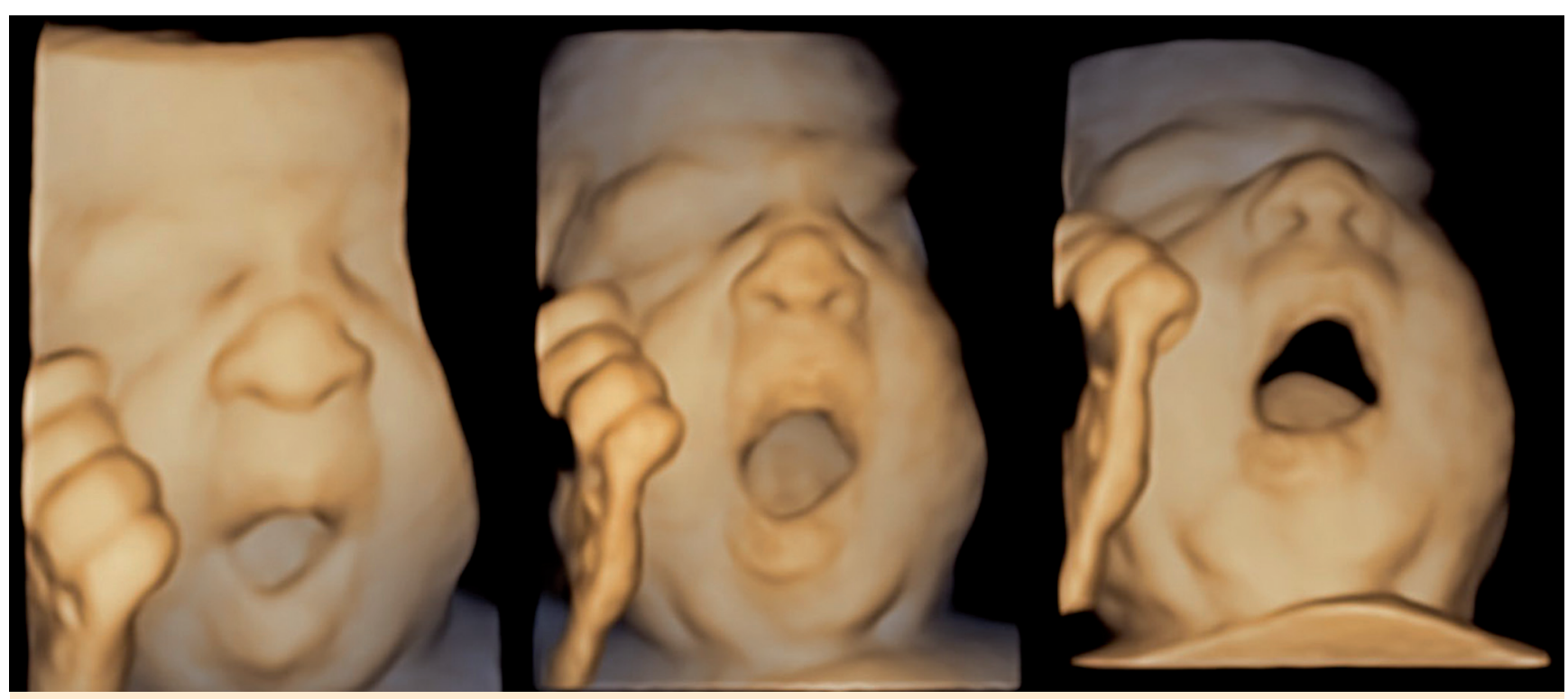

Abb. 1 Gähnbewegung eines Feten (35+6 SSW) im Oberflächenmodus. Die Aufnahmen sind Teil einer Bildsequenz, die bei einer 4-D-Aufnahme entstand. Das Öffnen des Mundes geht mit einer gleichzeitig nach unten gerichteten Zungenbewegung einher.

Fig. 1 Demonstration of a yawning fetus ( $35+6$ weeks' gestation) in the surface mode. The images are taken from a 4D-sequence. The opening of the mouth is associated with simultaneous downward movements of the tongue. 
Die fehlende Bestätigung der respiratorischen Hypothese brachte sodann die sog. „Arousal“-Hypothese hervor. „Arousals“ sind definiert als eine generelle Aktivierung der Gehirntätigkeit, die vom Hirnstamm ausgeht und zu Zentren des autonomen Nervensystems führt, um von dort aus dann in die kortikalen Bereiche zu gelangen. Viele Forscher [7-11] propagierten, dass Gähnen für die homöostatische Regulation der Vigilanz und den Erregungszustand des Gehirns verantwortlich ist. Sie berichteten, dass Gähnen während zunehmender Schläfrigkeit auftritt, entsprechend einem Zustand mit niedriger Vigilanz. Jedoch konnte kein gähnspezifischer Erregungseffekt auf das Gehirn oder das autonome Nervensystem beobachtet werden. Verhaltensstudien zeigten, dass Gähnen am häufigsten vor oder nach dem Schlaf auftritt [12]. Das zirkadiane Auftreten des Gähnens folgt dem individuellen Schlaf-Wach-Rhythmus, und das individuelle subjektive Gefühl der Schläfrigkeit korreliert mit erhöhten Gähnraten [13]. Kürzlich wurde eine andere physiologische Hypothese für das Gähnen aufgestellt. Die sogenannte Thermoregulationshypothese nimmt an, dass Gähnen die Gehirntemperatur reduziert, wenn diese erhöht ist. So wird angenommen, dass der Einstrom von kühler Luft während des Gähnvorgangs zu einem Abtransport der erhöhten Gehirntemperatur führt [14].

Auch wurden mehrere andere physiologische Regulationsfunktionen für das Gähnen propagiert.

Gähnen wird in vielen Kulturen als Zeichen von Langeweile und Schläfrigkeit interpretiert. Es handelt sich um ein Zeichen, das nahezu überall verstanden wird. Die Sozial- und Kommunikationshypothese postuliert, dass es sich beim Gähnen um eine nicht verbale Kommunikationsform handelt, die das Gruppenverhalten synchronisiert [15]. Nach den experimentellen Daten ist dies das einzige Modell, das soziale Aspekte wie Schläfrigkeit, verschiedene physiologische Zustandsformen und Sozialverhalten berücksichtigt, die durch Gähnen getriggert werden. Wie bereits zuvor erwähnt, können verschiedene physiologische Stadien, wie Schläfrigkeit und Langeweile, Gähnen hervorrufen [3]. Das ansteckende Gähnen stellt einen wohlbekannten Effekt beim Menschen dar [2, 16]. Bei Kindern kann diese Form des ansteckenden Gähnens nicht vor einem Alter von 5 Jahren ausgelöst werden. Dies bedeutet, dass es sich um einen Mechanismus handelt, der sich während der Kindheit entwickelt [17]. Im Tierreich kann dies in ähnlicher Weise bei den Schimpansen, aber nicht bei den Löwen gefunden werden [16]. Es scheint, dass es bei Tieren gefunden wird, die eine enge soziale und emotionelle Bindung haben. Soziale Verhaltensmuster haben einen wichtigen Einfluss auf die Häufigkeit des Gähnens. Im Tierreich beinflusst die hierarchische Position innerhalb der Gruppe die Gähnfrequenz: der Anführer der Gruppe zeigt häufigeres Gähnen als die Nachgeordneten [18]. Beim Menschen hingegen hat die Anwesenheit von anderen Personen eher einen unterdrückenden Effekt, was die Gähnhäufigkeit angeht.

Gähnbewegungen können auch bei menschlichen Feten beobachtet werden ( $\mathbf{A}$ Abb. 1). Nach De Vries und Mitarbeitern [19, 20] handelt es sich hierbei um nicht repetitive Bewegungen, ähnlich dem Gähnen nach der Geburt. Es umfasst ein weites Öffnen des Kiefers, gefolgt von einem schnellen Schließen. Zusätzlich zu diesem Verhaltensmuster konnten Van Woerden und Mitarbeiter [21] Grimassen und Zungenbewegungen beobachten. Die Mehrzahl dieser Bewegungen sind in den Verhaltensstadien $1 \mathrm{~F}$ (ruhiger Schlaf) und 2F (aktiver Schlaf) zu sehen, wobei die fetalen Bewegungen denen bei Neugeborenen gleichen. Fetales Gähnen kann ab 11 Schwangerschaftswochen beobachtet werden, wobei on of the brain activity that progresses from brain stem structures to centers of the autonomic nervous system and to distributed cortical areas. Many researchers [7-11] proposed that yawning might be responsible for the homeostatic regulation of the vigilance and brain arousal level. They reported that yawns occur during progressive drowsiness, which is compatible with a state of low vigilance. However, no specific arousing effect of yawning on the brain or autonomic nervous system could be observed. Behavioral observation studies reported that yawns occur most frequently before and after sleep [12]. The circadian distribution of the yawns follows the individual sleep-wake rhythm and the individual subjective feeling of drowsiness correlates with increased yawning rates [13].

Recently, another physiological hypothesis for the yawning has been postulated. The so called thermoregulation hypothesis proposes that yawning might cool down the brain when the temperature increases. It is suggested that the inflow of cool air during yawning ventilates heat of the brain [14].

Many other variations of a regulatory function of yawning on body physiology have been proposed.

In many cultures, yawning is interpreted as a sign of boredom and sleepiness. It seems to communicate a message that is almost universally understood. The social and communication hypothesis suggests that yawning is a non-verbal form of communication that synchronizes the behavior of a group [15]. According to the experimental data, it is the only model that takes into account social aspects such as the contagiousness of yawning, different physiological states and social behavior that are triggered by yawning. As previously mentioned, different physiological states such as drowsiness and boredom can precede yawning [3]. The contagious yawning has a well-known effect in humans $[2,16]$. In children, no contagious yawning can be induced before the age of five, suggesting a mechanism that has to develop during childhood [17]. In case of animals, contagious yawning is observed in chimpanzees, but not in lions [16]. It seems to be found in animals that are socially and emotionally close to each other. Social behaviors were found to have an important impact on the yawning rate. In animals, the hierarchical position within a social group influences the frequency of yawning: group leaders initiate more yawns than the subordinate group members [18]. In humans, the presence of other humans may even have a suppressive effect on the yawning rate.

The yawning motion can also be observed in the human fetuses (० Fig. 1). According to De Vries and co-workers [19, 20], yawning is a non-repetitive movement similar to the yawn observed after birth. It includes wide opening of the jaws, followed by a quick closure. In addition to these patterns, Van Woerden and colleagues [21] observed grimace and tongue protrusion movements. The majority of these movements are seen during behavioral states $1 \mathrm{~F}$ (quitet sleep) and $2 \mathrm{~F}$ (active sleep) and the fetal movements are similar to those in neonates. Fetal yawning can be observed as early as at 11 weeks of gestation without a particular gestational age-related pattern and in most cases it occurs during sleep activity [22].

In 1995, Sepulveda and Mangiamarchi [22] published a case report about repetitive yawning in a healthy 27 -week fetus during 7 minutes of observational time. They observed several yawning movements and reported that the duration of each yawn ranged between 4-6 seconds. One year later another case report from Masuzaki [23] confirmed the observation of the former paper regarding the duration of yawning, but not the frequency of this 
kein gestationsabhängiges Muster nachzuweisen ist. Die meisten Bewegungen treten in der Schlafphase auf [22].

1995 berichteten Sepulveda und Mangiamerchi [22] über einen Fall mit repetitivem Gähnen bei einem 27 Wochen alten Fetus über einen Zeitraum von $7 \mathrm{~min}$. Sie beobachteten mehrere Gähnbewegungen und fanden heraus, dass die Gähndauer zwischen 4 und $6 \mathrm{~s}$ betrug. In einem weiteren Fallbericht ein Jahr später konnten Masuzaki [23] die Dauer des Gähnvorganges bestätigen, aber nicht die Frequenz des Reflexes. Sie konnten lediglich eine nicht repetitive Bewegung bei der Farbdoppleruntersuchung beobachten.

In einer weiteren Studie von Petrikovsky und Mitarbeitern [24] konnte die Gähnaktivität bei 38 normalen und High-Risk-Feten zwischen 36 und 40 Schwangerschaftswochen während der Ultraschalluntersuchung beobachtet werden. Sie berichteten, dass der Gähnvorgang eine isolierte Mundbewegung darstellt, die mit einem langsamen Öffnen des Mundes und einer gleichzeitig nach unten gerichteten Zungenbewegung einhergeht. Diese Phase beanspruchte 50-75\% des Gähnzyklus. Nach Erreichen des Öffnungsmaximums bleib der Mund für 2-8 s geöffnet. Wachstumsretardierte Feten zeigten Gähnmuster mit isolierten Gähnbewegungen ähnlich denjenigen bei gesunden Feten. Ungewöhnliche Gähnsalven wurden bei anämischen Feten beobachtet. Hierbei könnte es sich um einen kompensatorischen Prozess handeln, um den venösen Rückfluss zum Herzen zu erhöhen.

Mit der raschen Entwicklung des 4-D-Ultraschalls [25-27] konnten neue Möglichkeiten geschaffen werden, das fetale Bewegungsverhalten zu kontrollieren. Gesichtsausdruck und -bewegungen im Oberflächenmodus können nun herangezogen werden, funktionelle neurologische Auffälligkeiten zu beurteilen. Ein neurologischer Entwicklungs-Score für das fetale Bewegungsverhalten unter 4-D-Ultraschallsicht wurde von Kurjak et al. publiziert [27]. Dabei stellt der Gähnreflex ein Bestandteil des ScoreTests dar.

Contact author for the list of references reflex. They observed just a single non-repetitive movement in Color Doppler imaging.

Petrikovsky and colleagues [24] studied yawning activity in 38 normal and high-risk fetuses between 36-40 weeks of pregnancy during ultrasound examination. They reported that yawning was represented by isolated mouthing movements and consisted of slow opening of the mouth with simultaneous downward movements of the tongue. This phase comprises $50-75 \%$ of the yawning cycle. After reaching the maximum opening, the mouth remained wide open for 2-8 seconds. Growth-restricted fetuses demonstrated yawning patterns consisting of isolated yawns similar to those seen in healthy fetuses. Unusual bursts of fetal yawning activity were recorded in anemic fetuses, which may represent a compensatory process to increase venous return to the heart.

The rapid development of 4D ultrasound [25-27] had provided new opportunities for studying the fetal movement patterns. Facial expression and movements are now used in the surface mode to evaluate functional neurological abnormalities. Kurjak et al. [27] had proposed an antenatal neurodevelopment scoring test for the assessment of the fetal behavior using 4D ultrasound, where yawning is a reflex to be evaluated.

\section{S. Pashaj, E. Merz, Zentrum für Ultraschalldiagnostik, Kranken-} haus Nordwest, Frankfurt/Main

E-Mail: emerz@uni-mainz.de 